\title{
Williams, David.
}

\section{Milton's Leveller God.}

Montreal: McGill-Queen's University Press, 2017. Pp. xix, 494. ISBN 978-07735-5034-6 (paperback) \$39.95.

As he informs us in his preface, David Williams taught Milton for over four decades, even while his major research area was twentieth-century studies. Milton's Leveller God has clearly been a labour of love for this now retired scholar, but it is much more than that. As John Rogers asserts in the back blurb, "This beautifully written book is one that all scholars of Milton will have no choice but to read and contend with." This review intends to corroborate that claim, with the view that no one interested in Milton will be able to ignore Williams's argument, and that his argument is likely to be contentious.

Initially, Williams offers his rhetorical goal as complementary to Nigel Smith's Is Milton Better Than Shakespeare? (2008), which asserts that "Milton's theology of free will continues to be a great cornerstone of Western liberal democracy," and so his disappearance from the curriculum at many universities is lamentable. Yet Williams insists that the poet "is not a classical republican, given to political 'elitism' [...] but is increasingly a social egalitarian" (xi). The key to such egalitarianism is Milton's (apparently at first inchoate or surreptitious) sympathy with Leveller authors, most significantly John Lilburne, Richard Overton, and William Walwyn. The critical problem to be overcome here is that while such sympathy has been "suspected," the "evidence has remained elusive" (6). Although an early modern scholar, I do not work closely on the history of the civil war; I teach Milton periodically as my own labour of love, and to prevent the kind of lamentable absence from the curriculum mentioned above. Seasoned Milton scholars may very well respond differently to Williams's initial historical discussion; my impression was that these chapters take the reader deeply but too quickly into historical contexts that require further corroboration and expansion. The claims for Milton's Leveller sympathies seemed often highly persuasive, at other times somewhat doubtful. The discussion in particular invites a revisiting, or a closer perusal, of two studies with which Williams contends: Nicholas von Maltzahn's Milton's History of Britain: Republican Historiography in the English Revolution (1991), which presents a more residually "elitist" Milton, and Blair Worden's Literature 
and Politics in Cromwellian England: John Milton, Andrew Marvell, Marchamont Nedham (2007).

When Williams turns to the text of Paradise Lost, no reader will be unmoved, since he presents perhaps the mostly grandly revisionist reading of the poem since Fish's Surprised by Sin. The title of the book suggests as much. Who would expect a literary character who has received as much bad press as Milton's apparently irascible and vindictive monarchical tyrant to actually intend the levelling of all hierarchy? Williams's lucid introductory summation hardly prepares us for what is to come: "The unheard story in Paradise Lost largely concerns an hermaphroditic deity who brings a universe into being out of the divine body, who genders metaphysically feminine the will of creatures liberated from 'his' divine being. With one stroke, Milton overturns the ontological hierarchy of soul/body that has traditionally justified the social hierarchy of male/female and a political hierarchy of ruler/ruled" (xiv). Williams achieves this revision partly through an emphasis on the "dramatic" elements of the epic, involving over the course of the poem a "ubiquitous ethic of testing" (327). The critic at one point focuses on how the apparently benign God of book 8 tests Adam's understanding to prove his real need for an equal companion. But the more notorious appearance of God in book 3 also consists of a test of the Son's love and integrity_ "The Father has merely played the scene in accents of rage in order to create the requisite conditions of freedom for the Son to act [benevolently]" (158) — and in fact culminates in, or at least foreshadows, a dramatic levelling of all heavenly hierarchy: "For the first time in the poem, the angels are addressed as [God's] equals - 'ye Gods' [...] Continuing changes in the forms of social address will be our clearest and most enduring sign of the ongoing evolution of political forms in Heaven" (166). Such interpretations, dramatically and politically, may strike some as less persuasive than Williams's identification of Satan with Cromwell, under whose service Milton clearly experienced increasing disenchantment.

Even more surprising, however, than the recuperation of God may be Williams's interpretation of Raphael. Certainly not a favourite character of any reader believing in Milton's progressive politics, especially his gender politics, Williams goes so far as to hold Raphael largely responsible for the Fall: "Raphael exhibits a lack of self-awareness and logical consistency that contributes much more than he knows to the Fall of man" (268-69). When it comes to the Fall, Williams presents (correctly, I think) the separation scene as the key. Adam, 
whose reason has been corrupted by Raphael's hierarchical and patriarchal lecture at the end of book 8, undermines his own (egalitarian) love for Eve, a blow that renders her more vulnerable to Satan's temptation. Disconcertingly, however, Williams downplays the most crucial passage in the exchange between Adam and Eve - "Go; for thy stay, not free, absents thee more"-by dismissing critical attention here as "entirely academic" (287). While I am deeply attracted, with Williams, to a revolutionary rather than a conservative or patriarchal Milton, Williams's reading at times seems awfully hard on Adam, as opposed to Eve (who, virtually, can do no wrong). In fact, the interpretation, in spite of its revolutionary and "dramatic" emphasis, occasionally threatens to drain the poem of its dialectical tension. For me, Paradise Lost remains a text embodying, in Waldock's words, a clash between what it asserts, on the one hand, and what it compels us to feel, on the other-but still, contra Waldock, a poem whose astonishing richness is driven by unconscious meaning - and neither Fish's nor Williams's reading resolves that. Nevertheless, those who care anything about Milton must read this provocative study, and decide for themselves.

IAN MCADAM

University of Lethbridge 